\title{
PENGARUH FIRMSIZE, DEBT TO EQUITY (DER), DAN AKTIVITAS (TATO) TERHADAP PROFITABILITAS PERUSAHAAN SUBSEKTOR PROPERTY DAN REAL ESTATE YANG TERDAFTAR DI BURSA EFEK INDONESIA PERIODE 2013-2017
}

\author{
Mesrawati $^{1}$, Carlos Sihombing ${ }^{2}$, Ervina Samjaya $^{3}$ \\ 1,2,3 Program Studi S-1 Akuntansi Keuangan Universitas Prima Indonesia (UNPRI), Jl.Belanga No.1, Medan, \\ 20112, Indonesia
}

Email : Carlossihombing31@gmail.com

\begin{abstract}
This purpose this research to get tasted on the effect of Firm Size, Debt to Equity, and Activity on Profitability in the property and real estate sub-sector companies listed on the Indonesia Stock Exchange in 2013-2017. The research sample consisted of 29 companies selected through Purposive sampling techniques. The data used in this study is secondary data, by collecting data or information in the form of financial statements needed from idx. The analytical method used is multiple regression analysis and assumption test. The research subjects were property and real estate companies listed on the Indonesia Stock Exchange for the period 2013-2017. From the results of the discussion showed that partially with the test, Firm Size variable, Debt to Equity and Activity had an effect on Profitability. Simultaneous results of independent variables; Firm Size, Debt to Equity and Activities with the F test, together have an effect on Profitability. The coefficient of determination shows that independent variables are able to influence the dependent variable.Keywords: firmsize,debt to equity, aktivitas.
\end{abstract}

Keywords : Firm size, debt to equity, activity

\section{PENDAHULUAN}

Industri property dan real estate salah satu sektor yang memberikan acuan berkembangnya ekonomi dalam suatu negara. Perkembangan pada sektor ini tentu saja mampu menyerap tenaga kerja yang jumlahnya cukup besar, dan mampu menarik dan mendorong sektor-sektor lainnya. Semakin tinggi tingkat profitabilitas menunjukkan bahwa perusahaan menghasilkan kinerja yang baik dan sebagai tolak ukuran apakah pemilik perusahaan atau pemegang saham dapat memperoleh tingkat pengembalian yang pantas. Kebijakan otoritas terkait sektor property yang saling bersinergi, dipercaya akan mampu mempercepat perbaikan kinerja sektor property.

\section{TINJAUAN PUSTAKA}

Didirikannya suatu perusahaan adalah untuk memperoleh laba atau profit. Dari nilai profitabilitas dan kekonsistenan suatu perusahaan maka dapat dilihat seberapa mampu perusahaan bertahan dalam bisnisnya. Pemenuhan dana perusahaan berasal dari sumber eksternal dan juga internal .karena itu juga mempengaruhi tingkat profitabilitas perusahaan. Apabila dana pinjaman perusahaan lebih besar dari modal sendiri,maka otomatis akan mengurangi profitabilitas perusahaan. Selain dari utang jangka panjang yang pada umumnya tinggi,pihak perusahaan dapat juga berakhir dengan membayar bunga utang sepanjang periode yang tidak membutuhkan dana tersebut. 
Tabel 1. Fenomena Firm Size, Debt to Equity dan Aktivitas Pada Perusahaan Subsektor Property dan Real Estate Tahun 2013-2017

\begin{tabular}{crrrrr}
\hline NAMA & TAHUN & \multicolumn{1}{c}{ ASET } & \multicolumn{1}{c}{ HUTANG } & PENJUALANN & LABA BERSIH \\
EMITEN & & & & & \\
\hline & 2013 & $9,298,245,408$ & $5,195,736,526$ & $3,029,797,151$ & $1,136,547,541$ \\
PT.PAKUWON & 2014 & $16,770,742,538$ & $8,487,671,758$ & $3,872,272,942$ & $2,597,078,888$ \\
JATI Tbk & 2015 & $18,778,122,467$ & $9,323,066,490$ & $4,625,052,737$ & $1,408,605,517$ \\
(PWON) & 2016 & $20,674,141,654$ & $9,654,447,854$ & $4,841,104,813$ & $1,776,412,002$ \\
& 2017 & $23,358,717,736$ & $10,567,227,711$ & $5,717,537,579$ & $2,002,490,448$ \\
& 2013 & $1,549,674,922,146$ & $402,415,984,925$ & $418,118,999,949$ & $198,210,213,964$ \\
PT.RODA & 2014 & $1,643,441,092,309$ & $291,666,592,282$ & $431,414,723,990$ & $232,634,563,044$ \\
VIVATEX Tbk & 2015 & $1,872,158,609,529$ & $282,593,660,798$ & $422,254,497,423$ & $260,638,132,889$ \\
(RDTX) & 2016 & $2,101,753,788,854$ & $273,290,660,870$ & $406,872,943,034$ & $258,948,179,433$ \\
& 2017 & $2,280,461,717,989$ & $225,499,951,528$ & $395,780,873,819$ & $248,246,602,835$ \\
PT.AGUNG & 2013 & $19,679,908,990$ & $12,467,205,599$ & $4,901,191,373$ & $930,240,497$ \\
PODOMORO & 2014 & $23,686,158,211$ & $15,223,273,846$ & $5,296,565,860$ & $983,875,368$ \\
LAND Tbk & 2015 & $24,559,179,988$ & $15,486,506,268$ & $5,971,581,977$ & $111,8073,171$ \\
(APLN) & 2016 & $25,711,953,382$ & $15,741,190,637$ & $6,006,952,123$ & $93,973,7108$ \\
& 2017 & $28,790,116,014$ & $17,293,138,465$ & $7,043,036,602$ & $188,258,1400$ \\
\hline
\end{tabular}

Dari Tabel 1 menunjukan bahwa fenomena yang terjadi pada PT.PWON, fenomena terjadi pada periode 2014-2015 yang seharusnya ketika Aset naik maka total laba naik. Tapi pada PT.PWOM aset mengalami penurunan sebesar $11,9 \%$ dan total laba mengalami kenaikan sebesar 45,7\%. Dimana sehararusnya total laba mengalami penurunan. PT.RDTX, fenomena terjadi pada periode 2013-2014 yang seharusnya ketika hutang naik laba mengalami penurunan, tapi pada PT. RDTX hutang mengalami penurunan sebesar $27,5 \%$ dan total laba mengalami kenaikan sebesar 17,3 \%. PT. APLN, fenomena terjadi pada periode 2015-2016 yang seharusnya ketika penjualan naik maka laba naik, tapi pada PT APLN penjualan mengalami kenaikan sebesar 5,9\% dan total laba mengalami penurunan sebesar $15,9 \%$. Berdasarkan uraian diatas maka dapat identifikasi masalah bahwa:

1. Kenaikan ukuran perusahaan tidak selalu diikuti dengan kenaikan pada profitabilitas.

2. Kenaikan debt to equity ratio tidak selalu diikuti dengan penurunan profitabilitas.

3. Kenaikan aktivitas tidak selalu diikuti dengan kenaikan pada profitabilitas.

4. Penurunan debt to equity ratio serta kenaikan ukuran perusahaan dan kenaikan aktivitas tidak selalu diikuti dengan peningkatan pada profitabilitas.

Berdasarkan identifikasi masalah yang didapat masalah yang dapat dirumuskan adalah seberapa besar pengaruh ukuran perusahaan, debt to equity dan aktivitas terhadap profitabilitas pada perusahaan property dan real estate yang terdaftar di Bursa Efek Indonesia periode 2013-2017? Hasil dari penelitian ini diharapakan mampu menambah pengetahuan dan pemahaman bagi peneliti lainnya dalam firm size, debt to equity dan aktivitas dan profitabilitas, dan juga sebagai bahan masukan dalam mempertimbangkan pengamnbilan keputusan investasi yang tepat.

Firm size. Firm size adalah semakin besar suatu perusahaan maka akan semakin besar pula tingakat utangnya. Ukuran perusahaan dilihat dari total aset yang dimiliki perusahaan tersebut yang dapat digunakan untuk kegiatan operasional perusahaan. Perusahaan dengan ukuran lebih besar lebih berani mengeluarkan saham baru dalam memenuhi kebutuhan untuk membiayai pertumbuhan penjualan dibandingkan dengan perusahaan yang lebih kecil. Menurut Munawir (2007:83), perusahaan yang harga produksi per unit relatif rendah akan mempunyai earning yang lebih stabil. Perusahaan dengan ukuran besar dapat menghasilkan produk dengan biaya rendah yang merupakan salah satu unsur pencapaian laba.

\section{Ukuran Perusahaan $=\boldsymbol{L n}($ Asset $)$}


Tujuan dari analisis ukuran perusahaan. Tujuan dari analisis ukuran perusahaan adalah mengidentifikasi setiap kelemahan keuangan yang dapat menimbulkan masalah di masa yang akan datang, dan menentukan kekuatan yang dapat dipergunakan.

Debt to equity. Debt to equity adala perbandingan antara seluruh hutang dengan modal yang dimiliki, dan bagaimana suatu perusahaan mendanai kewajibannya. Menurut Kasmir (2008:157), debt to equity adalah rasio yang digunakan untuk menilai utang dengan ekuitas. Semakin lama jadwal jatuh tempo utang perusahaan, tampaknya makin mahal pendanaannya. Selain dari biaya peminjam jangka panjang yang umumnya lebih tinggi, perusahaan dapat juga berakhir dengan membayar bunga utang sepanjang periode yang tidak membutuhkan dana tersebut. Menurut Hantono (2017 : 8), debt to equity merupakan rasio yang menunjukkan sejauhmana modal sendiri menjamin seluruh utang.

Tujuan Debt to Equity Ratio. Debt to equity sebagai tolak ukur kinerja keuangan diantaranya mengukur tingkat penggunaan utang terhadap total shareholder's equity yang dimili perusahaan.

$$
\text { Debt to Equity Ratio }=\frac{\text { Total Utang }}{\text { Modal Sendiri }}
$$

Rasio Aktivitas. Rasio aktivitas adalah seberapa efektif perusahaan memanfaatkan aset mereka untuk mengasilkan pendapatan. Menurut Hery (2015:167), rasio yang digunakan untuk mengukur tingkat efisiensi atas pemanfaatan sumber daya yang dimiliki perusahaan. Perputaran total aktiva, menunjukkan bagaimana efektivitas perusahaan menggunakan aktiva untuk menciptakan penjualan dan mendapatkan laba. Semakin tinggi rasio total asets turnover berarti, semakin efisien penggunaan aktiva didalam mengasilkan penjualan. Dalam rasio ini perusahaan atauy manajemen dapat mengetahui berapa lama piutang mampu ditagih selama satu periode.

Tujuan Rasio Aktivitas. Untuk mengetahui seberapa besar perusahaan telah melakukan penjualan dengan menggunakan seluruh aktiva yang dimilikinya. Rasio ini memberikan informasi seberapa besar kontribusi setiap aktiva untuk menciptakan penjualan, untuk mengukur berapa kali dana yang ditanamkan dalam aktiva tetap berputar dalam satu periode, untuk mengukur penggunaan aktiva perusahaan dibandingkan dengan pejualan.

$$
\text { Total assets turnover }=\frac{\text { Sales }}{\text { Total Assets }}
$$

Rasio aktivitas ini memakai total aset turn over

Teori Profitabilitas. Profitabilitas adalah mengukur kemampuan perusahaan laba dengan menggunakan sumber-sumber yang dimiliki perusahaan seperti aktiva, modal atau penjualan perusahaan. Menurut Sartono (2010:249) profitabilitas merupakan faktor penting dalam menetukan struktur modal. Dengan laba ditahan yang besar, perusahaan akan lebih senang menggunakan laba ditahan sebelum menggunakan utang.

\section{Tujuan Profitabilitas}

1. Untuk mengetahui dan menilai kemajuan atau pertumbuhan suatu perusahaan.

2. Untuk menganalisis faktor-faktor yang memengaruhi peningkatan kemajuan perusahaan.

3. Mengukur kemampuan perusahaan dalam memperoleh laba melalui seluruh kemampuan dan sumber yang ada seperti kegiatan penjualan, kas, modal, jumlah karyawan, jumlah cabang dan unsur unsur laporan keuangan.

4. Menggambarkan tentang tingkat efektifitas manajemen dalam melaksanakan kegiatan operasional. 


$$
\text { ROA }=\frac{\text { Earnings after taxes }}{\text { Total Assets }}
$$

Profitabilitas ini menggunakan Return on Assets. Peneliti sebelumya yang melakukan penelitian yang berhubungan dengan profitabilitas. Hantono dalam penelitiannya yang berjudul "Pengaruh Current Ratio dan Debt to Equity Ratio Terhadap Profitabilitas". Dari hasil penelitian yang dilakukan Current Ratio , Debt to Equity berpengaruh secara parsial terhadap Profitabilitas dan begitu juga Current Ratio, Debt to Equity berpengaruh secara simultan terhadap Profitabilitas. Ukuran perusahaan termasuk sebagai faktor dari struktur keuangan. Salah satu tolak ukur dari ukuran perusahaan adalah total aset atau aktiva dari perusahaan, dimana peningkatan total aset menunjukkan efektivitas dari seluruh penggunaan aktiva sehingga semakin besar aktivitas perusahaan yang diukur dari total aset maka akan semakin meningkatkan laba yang akan diterima oleh perusahaan.Semakin tinggi perputaran aktiva berarti semakin besar kemampuan perusahaan terhadap untuk menghasilkan penjualan dengan menggunakan setiap Rupiah aktiva. hal ini berarti semakin menurun kebutuhan perusahaan untuk menambah aktiva baru karena peningkatan penjualan, dan oleh karena itu akan menaikkan tingkat pertumbuhan berkelanjutan.

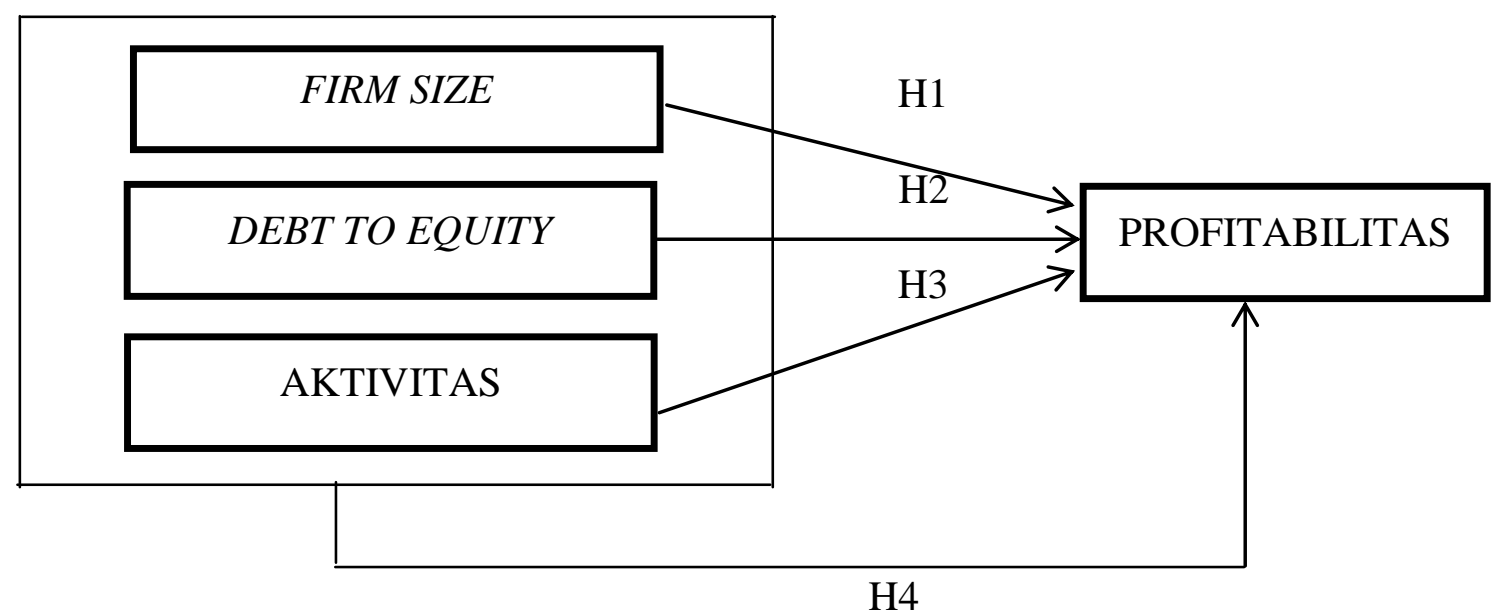

Gambar 1. Kerangka Konseptual

Hipotesis adalah suatu pernyataan yang pada waktu diungkapkan belum diketahui kebenarannya. Dari rumusan masalah, tujuan, teori, penelitian terdahulu, dan kerangka konseptual maka hipotesis dalam penelitian ini adalah : Firm size, debt to equity, aktivitas berpengaruh secara parsial terhadap profitabilitas pada Perusahaan sub sektor property \& real estate periode 2013-2017. Firm size, debt to equity, dan aktivitas berpengaruh secara simultan terhadap profitabilitas pada Perusahaan sub sektor property \& real estate periode 2013-2017.

\section{METODE PENELITIAN}

Jenis dan sumber data. Pada penelitian ini jenis data yang digunakan adalah data sekunder. Sumber data diperoleh dari laporan keuangan perusahaan subsektor property dan real estate yang terdaftar di Bursa Efek Indonesia Tahun 2013-2017 dengan website www.idx.co.id. 
Sampel dan teknik pengumpulan sampel. Sampel pada penelitian ini berjumlah 145 , yang diambil dari teknik pengumpulan sampel yaitu purposive sampling dengan pertimbangan tertentu.

Tabel 2. Kriteria pemilihan sampel

\begin{tabular}{llr}
\hline No & \multicolumn{1}{c}{ Keterangan } & Jumlah \\
\hline 1 & $\begin{array}{l}\text { Perusahaan sub sektor property \& real estate yang terdaftar di Bursa efek } \\
\text { Indonesia periode 2013-2017 }\end{array}$ & 48 \\
2 & $\begin{array}{l}\text { Daftar perusahaan yang tidak mempublikasikan laporan keuangannya secara } \\
\text { berturut-turut perusahaan sub sektor property \& real estate yang terdaftar di }\end{array}$ & \\
& $\begin{array}{l}\text { Bursa Efek Indonesia Periode 2013-2017 } \\
3\end{array}$ & \\
& $\begin{array}{l}\text { Daftar perusahaan yang mengalami kerugian perusahaan sub sektor property } \\
\text { \& real estate yang terdaftar di Bursa Efek Indonesia Periode 2013-2017. }\end{array}$ & $(9)$ \\
& Jumlah perubahan yang terpilih menjadi sampel penelitian & 29 \\
& Jumlah tahun \\
& Total perusahaan yang menjadi sampel penelitian 29x5 & 5 \\
\hline
\end{tabular}

Sumber : www.idx.co.id

Metode analisis. Pendekatan pada penelitian ini digunakan adalah metode kuantitatif yang digunakanunuk meneliti populasi dan sampel. Jenis penelitian ini adala deskriptif. Sifat penelitian ini adalah bersifat kausal, dimana adanya hubungan sebab akibat antara variabel dependen dengan variabel independen. Dalam peneletian ini, metode analisis data yang digunakan adalah metode analisis statistik dengan menggunakan software SPSS.Sebelum data di analisis, terlebih dahulu dilakukan uji asumsi klasik sebelum melakukan pengujian hipotesis. Untuk pengujian hipotesis dilakukan analisis regresi linier berganda. Model regresi digunakan sebagai berikut :

$$
\mathrm{Y}=\mathrm{a}+\mathrm{b} 1 \cdot \mathrm{X} 1+\mathrm{b} 2 \cdot \mathrm{X} 2+\mathrm{b} 3 \cdot \mathrm{X} 3+\mathrm{e}
$$

Dimana :

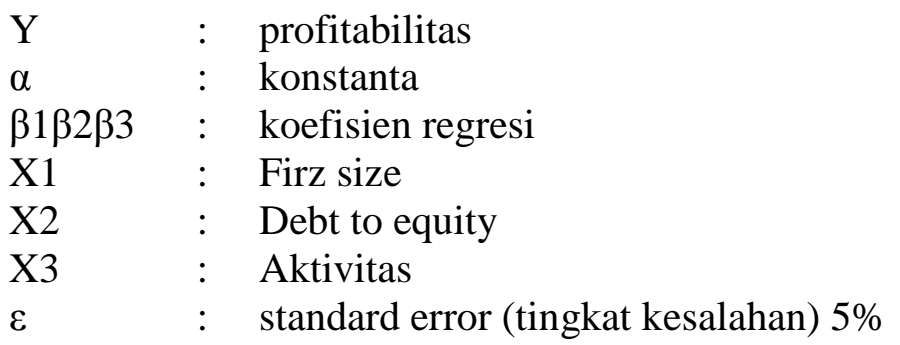

\section{HASIL ANALISIS DAN PEMBAHASAN}

4.1. Hasil analisis

Uji Normalitas

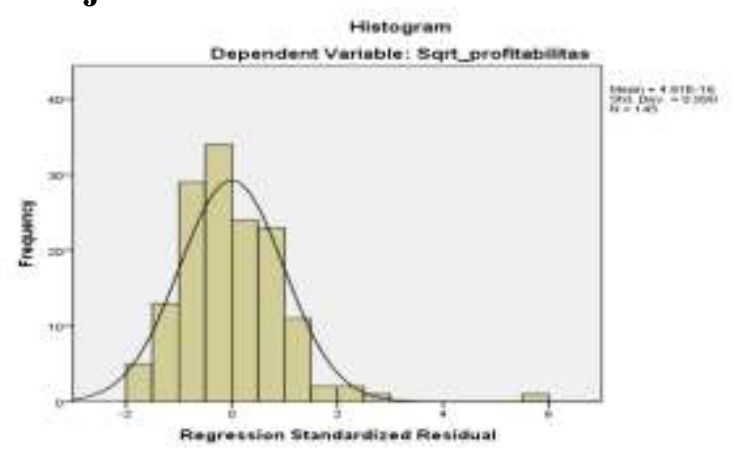


Salah satu cara termudah untuk melihat normalitas residual adalah dengan melihat grafik histogram yang membandingkan antara data observasi dengan distribusi yang mendekati distribusi normal. Pada grafik diatas menunjukkan bahwa garis membentuk satu garis diagonal, dan ploting data residual akan membandingkan dengan garis diagonal.

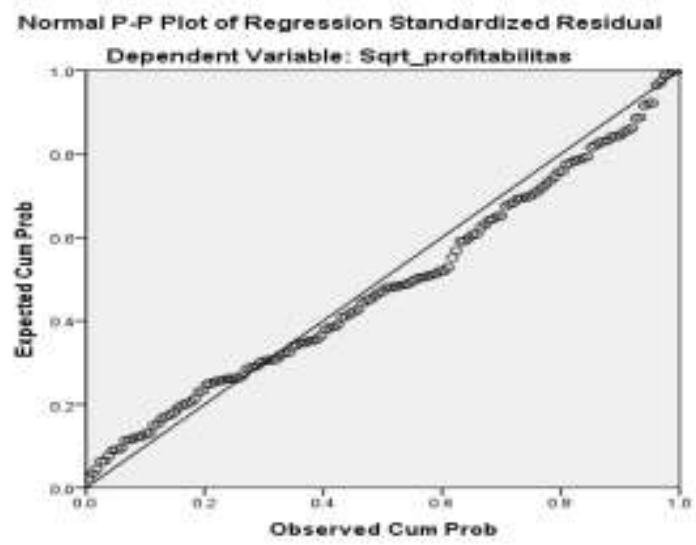

Dari grafik diatas, menunjukkan bahwa data terdistribusi normal dimana terlihat bahwa titiktitik mengikuti arah garis diagonal.

\section{Uji Multikolinearitas}

Tabel 3. Uji Multikolinearitas

\begin{tabular}{|c|c|c|c|c|c|c|c|c|c|c|c|}
\hline \multirow{2}{*}{\multicolumn{2}{|c|}{ Model }} & \multicolumn{2}{|c|}{$\begin{array}{l}\text { Unstandardized } \\
\text { Coefficients }\end{array}$} & \multirow{2}{*}{$\begin{array}{c}\begin{array}{c}\text { Standardized } \\
\text { Coefficients }\end{array} \\
\text { Beta }\end{array}$} & \multirow[b]{2}{*}{$\mathrm{t}$} & \multirow[b]{2}{*}{ Sig. } & \multicolumn{3}{|c|}{ Correlations } & \multicolumn{2}{|c|}{$\begin{array}{l}\text { Collinearity } \\
\text { Statistics }\end{array}$} \\
\hline & & B & $\begin{array}{l}\text { Std. } \\
\text { Error }\end{array}$ & & & & $\begin{array}{l}\text { Zero } \\
\text { order }\end{array}$ & Partial & Part & Tolerance & VIF \\
\hline \multirow[t]{4}{*}{1} & (Constant) & 0.069 & 0.166 & & 0.413 & 0.680 & & & & & \\
\hline & Sqrt_firmsize & -0.002 & 0.030 & -0.005 & -0.074 & 0.941 & -0.077 & -0.006 & -0.005 & 0.943 & 1.061 \\
\hline & Sqrt_debttoequity & 0.004 & 0.033 & 0.009 & 0.124 & 0.902 & 0.173 & 0.010 & 0.008 & 0.881 & 1.135 \\
\hline & Sqrt_aktivitas & 0.417 & 0.051 & 0.579 & 8.102 & 0.000 & 0.582 & 0.564 & 0.555 & 0.918 & 1.089 \\
\hline
\end{tabular}

a. Dependent Variable: Sqrt_profitabilitas

Pada masing-masing variabel nilai dari tolerance dan variance inflation factor (VIF) diketahui:

a. Variabel Firm size bebas dari multikolinearitas dikarenakan nilai dari tolerance 0,943 dan hasilnya menunjukkan berada diatas 0,1 dan nilai VIF 1,061 dan hasil memnunjukkan di bawah 10.

b. Variabel DER bebas dari multikolinearitas dikarenakan nilai dari tolerance 0,881 dan hasilnya menunjukkan berada diatas 0,1 dan nilai VIF 1,135 dan hasil memnunjukkan di bawah 10.

c. Variabel Firm size bebas dari multikolinearitas dikarenakan nilai dari tolerance 0,918 dan hasilnya menunjukkan berada diatas 0,1 dan nilai VIF 1,089 dan hasil memnunjukkan di bawah 10 


\section{Autokolerasi}

Tabel 4. Model Summary ${ }^{\mathrm{b}}$

\begin{tabular}{|c|c|c|c|c|c|c|c|c|c|c|}
\hline \multirow[b]{2}{*}{ Model } & \multirow[b]{2}{*}{$\mathbf{R}$} & \multirow[b]{2}{*}{$\begin{array}{c}\mathbf{R} \\
\text { Square }\end{array}$} & \multirow[b]{2}{*}{$\begin{array}{c}\text { Adjusted R } \\
\text { Square }\end{array}$} & \multirow[b]{2}{*}{$\begin{array}{l}\text { Std. Error of } \\
\text { the Estimate }\end{array}$} & \multicolumn{5}{|c|}{ Change Statistics } & \multirow[b]{2}{*}{$\begin{array}{l}\text { Durbin- } \\
\text { Watson }\end{array}$} \\
\hline & & & & & $\begin{array}{c}\text { R Square } \\
\text { Change }\end{array}$ & $\begin{array}{c}\mathbf{F} \\
\text { Change }\end{array}$ & df1 & df2 & $\begin{array}{c}\text { Sig. F } \\
\text { Change }\end{array}$ & \\
\hline 1 & $0.582^{\mathrm{a}}$ & 0.339 & 0.325 & 0.10916 & 0.339 & 24.107 & 3 & 141 & .000 & 1.991 \\
\hline
\end{tabular}

Pada uji autokolerasi dengan menggunakan uji Durbin-Watson menghasilkan nilai statistik sebesar $(\mathrm{DW})=1,991$ nilai ini akan dibandingkan dengan nilai pada tabel DurbinWatson á $=0,00$ dimana pada penelitian ini jumlah sampel 145 dan variabel independen sebanyak3. Dari jumlah tersebut maka dihasilkan $\mathrm{dL}=1,686$ dan $\mathrm{dU}=1,771$. Dw terletak antara Du dan $(4-d U)=1,771<1,991<2,009$ maka dapat disimpulkan bahwa tidak terdapat autokolerasi

\section{Uji Heteroskedastisitas}

Tabel 5. Coefficients ${ }^{\mathrm{a}}$

\begin{tabular}{|c|c|c|c|c|c|}
\hline \multirow[b]{2}{*}{ Model } & \multicolumn{2}{|c|}{ Unstandardized Coefficients } & Standardized Coefficients & \multirow[b]{2}{*}{$\mathbf{T}$} & \multirow[b]{2}{*}{ Sig. } \\
\hline & B & Std. Error & Beta & & \\
\hline 1 (Constant) & 0.069 & 0.166 & & 0.413 & 0.680 \\
\hline Sqrt_firmsize & -0.002 & 0.030 & -0.005 & -0.074 & 0.941 \\
\hline Sqrt_debttoequity & 0.004 & 0.033 & 0.009 & 0.124 & 0.902 \\
\hline Sqrt_aktivitas & 0.417 & 0.051 & 0.579 & 8.102 & 0.000 \\
\hline
\end{tabular}

Dari tabel diatas, dapat dilihat bahwa nilai Sig/Significance untuk masing-masing variabel sebagai berikut:

a. Pada variabel firm size terbebas dari heteroskidastiditas dikarenakan nilai significancenya $>5 \%$ yaitu sebesar 0,680 .

b. Pada variabel firm Der terbebas dari heteroskidastiditas dikarenakan nilai significancenya $>5 \%$ yaitu sebesar 0,0941 .

c. Pada varabel aktivitas terbebas dari heteroskidastiditas dikarenakan nilai significancenya $>5 \%$ yaitu sebesar 0,902 .

\section{Model Regresi}

1. Uji statistic t. Uji statistik digunakan untuk mengetahui apakah semua variabel independen berpengaruh secara parsial terhadap variabel dependen.

Tabel 6. Coefficients ${ }^{\mathrm{a}}$

\begin{tabular}{|c|c|c|c|c|c|}
\hline \multirow[b]{2}{*}{ Model } & \multicolumn{2}{|c|}{ Unstandardized Coefficients } & \multirow{2}{*}{$\frac{\text { Standardized Coefficients }}{\text { Beta }}$} & \multirow[b]{2}{*}{$\mathbf{T}$} & \multirow[b]{2}{*}{ Sig. } \\
\hline & B & Std. Error & & & \\
\hline 1 (Constant) & 0.069 & 0.166 & & 0.413 & 0.680 \\
\hline Sqrt_firmsize & -0.002 & 0.030 & -0.005 & $0.074^{-}$ & 0.941 \\
\hline Sqrt_debttoequity & 0.004 & 0.033 & 0.009 & 0.124 & 0.902 \\
\hline Sqrt_aktivitas & 0.417 & 0.051 & 0.579 & 8.102 & 0.000 \\
\hline
\end{tabular}


Hasil uji t variabel Firm size menghasilkan nilai signifikan sebesar 0,941>0,05. Hal ini menunjukkan variabel Firm size tidak memiliki pengaruh secara parsial terhadap profitabilitas. Variabel Debt To Equity juga menghasilkan nilai signifikan sebesar 0,902 > 0,05 yang berarti . Hal ini menunjukkan variabel der tidak memiliki pengaruh secara parsial terhadap profitabilitas. Hasil dari aktivitas menghasilkan nilai signifikan sebesar $0,000<0,05$ yang berarti bahwa variabel aktivitasmemiliki pengaruh secara parsial terhadap profitabilitas.

2. Uji statistic F. Uji statistic F dilakukan untuk mengetahui apakah variabel independen berpengaruh terhadap variabel dependen secara simultan.

Tabel 7. ANOVA ${ }^{\mathrm{a}}$

\begin{tabular}{lllllrr}
\hline & Model & Sum of Squares & df & Mean Square & F & Sig. \\
\hline 1 & Regression & 0.862 & 3 & 0.287 & 24.107 & $0.000^{b}$ \\
& Residual & 1.680 & 141 & 0.012 & & \\
& Total & 2.542 & 144 & & & \\
\hline
\end{tabular}

a. Dependent Variable: Sqrt_profitabilitas

b. Predictors: (Constant), Sqrt_aktivitas, Sqrt_firmsize, Sqrt_debttoequity

Berdasarkan hasil uji $\mathrm{F}$, nilai $\mathrm{F}$ hitung sebesar 24,107 dengan nilai sig $0,000<0,05$ menunjukkan bahwa variabel firm size, deb to equity, dan aktivitas berpengaruh secara simultan terhadap profitabilitas

\section{Uji koefisien determinasi}

Tabel 8. Model Summary ${ }^{b}$

\begin{tabular}{llccc} 
& Model & R & R Square & Adjusted R Square \\
\hline 1 & $0.582^{\mathrm{a}}$ & 0.339 & & 0.325 \\
\hline
\end{tabular}

Koefisien determinasi digunakan untuk mengetahui seberapoa besar firm size, debt to equity dan aktivitas terhadap profitabilitas yang dapat dilihat pada tabel diatas, dimana nilai koefisien determinasi disesuaikan (Adjusted $R$ Square) yaitu sebesar 32,5\% pengaruh profitabilitas dijelaskan oleh variasi firm size, debt to equity dan aktivitas.

\subsection{Pembahasan}

Dari hasil uji yang telah dilakukan bahwa Firm Size $\left(\mathrm{X}_{1}\right)$ berpengaruh secara parsial terhadap Profitabilitas (Y) pada perusahaan subsektor property dan real estate periode 20132017. Dimana jika aset mengalami kenaikan maka total laba akan naik. Aset yang dimiliki perusahaan mampu memberikan manfaat dikemudian hari. Dari hasil uji yang telah dilakukan bahwa Debt to Equity $\left(\mathrm{X}_{2}\right)$ berpengaruh signifikan secara parsial terhadap Profitabilitas (Y) pada perusahaan subsektor property dan real estate periode 2013-2017. Dimana jika hutang naik maka laba mengalami penurunan. Laba yang dihasilkan perusahaan akan digunakan untuk membiayai kewajiaban ataupun utang perusahaan. Dari hasil uji yang telah dilakukan bahwa Aktivitas $\left(\mathrm{X}_{3}\right)$ berpengaruh signifikan secara parsial terhadap Profitabilitas (Y) pada perusahaan subsektor property dan real estate periode 2013-2017. Dimana jika penjualan mengalami kenaikan dan begitupula dengan laba mengalami kenaikan. Aset pada suatu perusahaan dipengaruhi oleh besar kecilnya pendapatan. Dari hasil uji yang telah dilakukan bahwa Firm Size $\left(\mathrm{X}_{1}\right)$, Debt to Equity $\left(\mathrm{X}_{2}\right)$ dan Aktivitas $\left(\mathrm{X}_{3}\right)$ berpengaruh positif dan signifikan secara simultan terhadap Profitabilitas (Y) pada perusahaan subsektor property dan real estate periode 2013-2017 


\section{KESIMPULAN DAN SARAN}

\subsection{Kesimpulan}

Pada pengujian yang telah dilakukan terdapat masalah sehingga peneliti melakukan transform pada variabel independen dan dependen. Hasil pengujian yang peneliti dapatkan:

1. Variabel firm size, debt to equity tidak berpengaruh secara parsial terhadap profitabilitas sementara variabel aktivitas berpengaruh secara parsial terhadap profitabilitas berdasarkan hasil uji t maka : (a) Aktivitas berpengaruh secara positif terhadap profitabilitas; dan (b) Firm size,debt to equity tidak berpengaruh terhadap profitabilitas.

2. Varibel Firm size, debt to equity dan akivitas secara simultan atau bersama sama berpengaruh terhadap profitabilitas.

\subsection{Saran}

Dari hasil penilitian dapat diajukan saran sebagai berukut:

1. Perusahaan subsektor property dan real estate yang terdaftar di Bursa Efek Indonesia sekiranya mampu menghasilkan profit yang besar dari aset yang dimiliki dengan mengelola dengan baik, juga mampu memanfaatkan utang dengan efisien untuk menghasilkan profit, dimana utang tersebut digunakan untuk pengembangan perusahaan dan menutupi kekurangan kas, dan sekiranya mampu memanfaatkan sumber daya yang ada dengan baik.

2. Untuk peneliti selanjutnya, disarankan untuk meneliti data laporan keuangan yang terbaru [ada perusahaan subsektor property dan real estate.

\section{DAFTAR PUSTAKA}

Brigham \& Houston. Dasar-Dasar Managemen Keuangan. Ed. 11, Jakarta: Salemba Empat.

Ghozali,Imam. 2016. Aplikasi Analisis Multivariete Dengan Program IBM SPSS. Cetakan ketujuh. Semarang: Universitas Dipenogoro

Horne, James.C.Van \& John.M. 2010. Prinsip-prinsip Manajemen Keuangan. Edisi Duabelas. Jakarta : Salemba Empat.

Harmono. 2015. Manajemen Keuangan Berbasis Balance Scorecard. Cetakan keempat. Jakarta : PT. Bumi Aksara

Hantono. 2015. Pengaruh Current Ratio dan Debt to Equity Ratio Terhadap Profitabilitas Pada Perusahaan Manufaktur Sektor Logam Dan Sejenisnya Yang Terdaftar di Bursa Efek Indonesia Periode 2009-2013, Jurnal, Wira Ekonomi Mikroskil, Medan. 2017. Konsep Analisa Laporan Keuangan dengan Pendekatan Rasio dan SPSS. Yogyakarta : Deepublish.

Mulyawan,Setia. 2014. Manajemen Keuangan. Cetakan Pertama. Bandung : CV pustaka setia.

Munawir,. 2014. Analisis Laporan Keuangan. Edisi Keempat. Yogyakarta : Liberty.

Susanti, Jeni dan Made Dana Saputra. 2015. Pengaruh Working Capital, Firm Size, Debt Ratio, dan Financial Fixed Asset Ratio Terhadap Profitabilitas(Studi Pada Perusahaan Real Estate dan Property terdaftar di BEI tahun 2011-2014). Jurnal Valid.

Najmudin. 2011. Manajemen Keuangan dan Akuntansi Syar'iyyah Modern. Yogyakarta : Andi.

Raharjaputra,Hendra. 2009. Manajemen Keuangan dan Akuntansi. Jakarta Selatan : Salemba Empat.

Rodoni,Ahmad \& Herni Ali. 2014. Manajemen Keuangan Modern. Jakarta : Mitra Wacana Media.

Myers. 2006. Dasar-dasar Manajemen Keuangan. Jakarta: Erlangga. 